\title{
Theoretical And Methodological Basis Of Organizing Technical College Didactic Administration
}

\author{
Alsu Kamaleeva ${ }^{1}$, Natalya Nozdrina ${ }^{2}$ and Suriya Gilmanshina ${ }^{3}$ \\ ${ }^{1}$ Institute of Pedagogy, Psychology and Social Problems, 12 Isaeva str., Kazan, 420039, Republic of \\ Tatarstan, the Russian Federation; \\ ${ }^{2}$ Bryansk State Technical University, 241035, Bryansk, Kharkiv str., 10-B, the Russian Federation; \\ ${ }^{3}$ Kazan Volga Federal University, Department of Chemical Education, the Kremlin str., 18, Kazan, \\ Republic of Tatarstan, the Russian Federation
}

\begin{abstract}
The possibility of using multi-level methodology as a theoretic-methodological basis of the proposed concept is considered: at the level of modern philosophical theory of knowledge and logic of scientific research, at the level of general scientific principles and norms of any research, at the level of specific scientific methodology and at the level of implementing the idea of cognitive approach based on the analysis of the relevant pedagogical situation and the optimal fulfilling professional training of qualified middle-level specialists. The representation scheme of didactics as the theory of education and training in relation to the system of secondary vocational education is offered and the definition of the concept "system of technical college didactic administration" is revealed. It is proposed to distinguish three interrelated subsystems: educational, cognitive and controlling, consisting of two hierarchical interrelated parts - internal and external audit. The system of technical college didactic administration is a complex of interrelated didactic components (subsystems) aimed at optimal professional training of college graduates, involving the acquisition of personally significant qualities demanded by modern high-tech society, namely students' work skills, general and professional competencies and professional qualifications.
\end{abstract}

\section{Introduction}

- theoretic-methodological basis of organizing technical college didactic administration is defined;

- representation scheme of didactics as the theory of education and training in relation to the system of secondary vocational education is developed;

- concept of "a system of technical college didactic administration" is substantiated and introduced.

Philosophical dictionary defines the concept as "given in the unfolding, ideologically and meaningfully comprehensive, reasoned, coherent and complete presentation of the original scientific theory or versio $[4,5]$. 
Interpreting didactic administration process of technical colleges will be presented in our concept in four interdependent blocks:

- basis consisting of the fundamental approaches to the didactic administration organization process of technical colleges, pedagogical facts confirming the actuality of the problem; methodological basis of our concept; conceptual ideas of our research; theoretical part; applied part.

\section{Materials and methods}

As theoretical and methodological framework of our concept, we used a multilevel methodology, the first level of which is defined by the philosophy of knowledge and logic of scientific research (V. S. Bibler, I. Ducatos, T. Kuhn, M. Polanyi, Karl Popper) [4], and also methodology of social system administration, focused on meaningful impact on the subjects of the educational process to ensure coordination of their activities in achieving set objectives (V. I. Zagvyazinsky, I. A. Winter, V. I., M. I. Rozhkov, B. SchultsJ. D. Russell M. D. Merrill $[1,2,3]$ ) and administration methodology in the sphere of education (Yu. A. Konarzhevsky, V. A. Slastenin, P. I. Tretyakov, K. M. Ushakov, T. I. Shamova, K. Huereca, M. Tchoshanov, M. de la Piedra [5]).

The second level is on the grounds of the systems approach. It sets the general scientific principles and norms of our research (V. P. Bespalko, Yu. K. Babansky, A. R. Kamaleeva, M. Cruz, \& M. Tchoshanov [8], etc.), based on the theoretical foundations of the idea of a phased formation of mental actions, as well as on the didactic ideas of forming general educational parameters (V. P. Bespalko, Yu. K. Babansky, A. R. Kamaleeva, M. Cruz, \& M. Tchoshanov [8], etc.) and introducing various types of intercourse links (G. V. mukhametzyanova, R. L. Arroyo, \& M. A. Tchoshanov [7], etc.).

The third methodological concrete scientific level relies on the scientific foundations of the problem of managing secondary vocational education institutions (N. L. Serbaguna, G. I. Ibragimov, G. V. Mukhametzyanova, E. G. Hoda, B. Goldschmidt, M. Goldschmidt [11]), and also on the competence approach identified as fundamental ((E. F. seer, I. A. Zimnaya, G. I. Ibrahimov, A. R. Kamaleeva, J. P. Guilford, Lange M. [12,13], etc.), on activity approach (A.N. Leontiev, and others).

The fourth level of the methodology consists of the ideas of introducing a cognitive approach based on an analysis of the corresponding pedagogical situation (R. L. Atkinson, E. M. Braverman, Richardson John, V. E. Steinberg, L. Bertalanffy, S. Bickford [9, 10]) and optimal implementation of qualified mid-level specialists' professional training $(\mathrm{G}$. V. mukhametzyanova, J. D. Russell, B. Schults [16, 17], etc.);

The legal framework of the concept is based on certain documents of:

- international level: the Bologna Process (1999, Russia joined the Bologna Process in September 2003), Copenhagen Declaration (2002), European Employment Strategy (2003), Maastricht Communiqué (updated Copenhagen Declaration) (2004), Bruges Communiqué (2010), Europe 2020 Strategy;

- federal level: Constitution of the Russian Federation (1993), Law of the Russian Federation "On Education" (Article 68) (2012), National Doctrine of Education in the Russian Federation until 2015 (2000), State Program of Education Development for 20162020 (2015), The concept of long-term socio-economic development of the Russian Federation until 2020 (2008), the package of measures aimed at improving the system of secondary vocational education for 2015-2020 (2015), the order of the Ministry of Labor and Social Security of Russia No.831 of November 2, 2015 "On approval of the 50 most demanded in the labor market new and promising occupations, that require secondary vocational education" and others. 


\section{Results}

Consider the interpretation of the "didactic administration" concept. This concept consists of two interrelated concepts - "didactics" and "administration" $[1,2]$.

Therefore, the deputy head of the main education department of the Voronezh region administration, the Ph.D. in pedagogical science N.A. Koroleva believes that there is a necessity to carry out organizational and didactic administration of teachers' advanced training [1, 2]. N.M. Roganovsky, E.N. Roganovskaya and V.A. Antonov think that didactic control is applicable in search for a solution to problems. R.R. Turaev considers that the most effective way to improve the quality of education in the institutions of secondary vocational education is the reflexive-pedagogical administration of students' educational and cognitive activity based on different electronic-didactic means. The father and son Lvovs (Lvov L.V., Lvov D.L.) believe that managing students' educational and cognitive activity is a didactic condition for the formation of professional skills with a guaranteed result. At the same time, they consider that "the didactic process as a change in the state of the learning system can be represented by the following formula (V.P.Bespalko). DP $=\mathrm{M}+\mathrm{AF}+\mathrm{Am}$. where: $\mathrm{DP}$ is the didactic process, $\mathrm{M}$ is students' motivation to learn; AF is the algorithm of functioning (students' learning and cognitive activities); Am is the management algorithm, "managing this activity by the teacher or technical training aids" [3].

R.I. Ostapenko and L.A. Kolosova in the article "Approaches to developing information and didactic system of college students' vocational training (on the example of the information-mathematical cycle disciplines)" consider that "the information and didactic system is apposed ... as a set of interacting a teacher, a student and information in the learning process, based on the use of information and didactic support and administration" [6]. In this case, the means of information and didactic support in them is "a set of information, technical and educational support".

Viktor Ivanovich Sopin in his dissertation research "The didactic system of design and integrated use of teaching aids in vocational schools and lyceums" (2000) studies the possibilities of a "didactic design system and integrated use of teaching aids aimed at improving the efficiency, level and quality of training for integrated groups of professions in a multi-level continuing professional education"'[7].

N.N. Dvulichanskaya in her study "Didactic system of forming professional competence of secondary vocational education students in the process of natural science training" emphasizes the necessity for continuous general natural science education: from college to university.

F.P. Khakunova proves in her study that "learning efficiency can be significantly increased if developing and implementing a system of didactic conditions and methods for its improvement will take into full account the specificity of functioning psychological mechanisms for learning and structural, informational and functional features of the educational process". This position is very close to us, as in organizing didactic administration in technical colleges, in our opinion, it is necessary to pay great attention to developing all features and manifestations of each student's inductive-deductive thinking [8]. Therefore, using the principle of cognition in the process of organizing and controlling educational and cognitive activity in a college is decisive.

We regard the subject of study of didactics as many scientists (B.P. Esipov, N.A. Sorokin, G.G. Ibragimov, and others) regard the theory of education and training. And education is the result of learning. And education, as it is noted by the corresponding member of the Russian Academy of Education, G.G. Ibragimov, consists of three systems the system of "knowledge and skills on the fundamentals of science; the system of relations 
to the outside world (scientific worldview) and the totality of cognitive powers and abilities of the individual (memory, mental operations, etc.) [7].

In our opinion, the system of internal and external control should be added to this tandem. Then the didactic as a theory of education and training can be represented schematically (Figure 1).

- the system of "knowledge and skills and competencies [8,9].

- the system of relations to the outside world (scientific worldview)

- the totality of cognitive powers and abilities of the individual (memory, mental operations, etc.)

- the system of internal control

- the system of external control

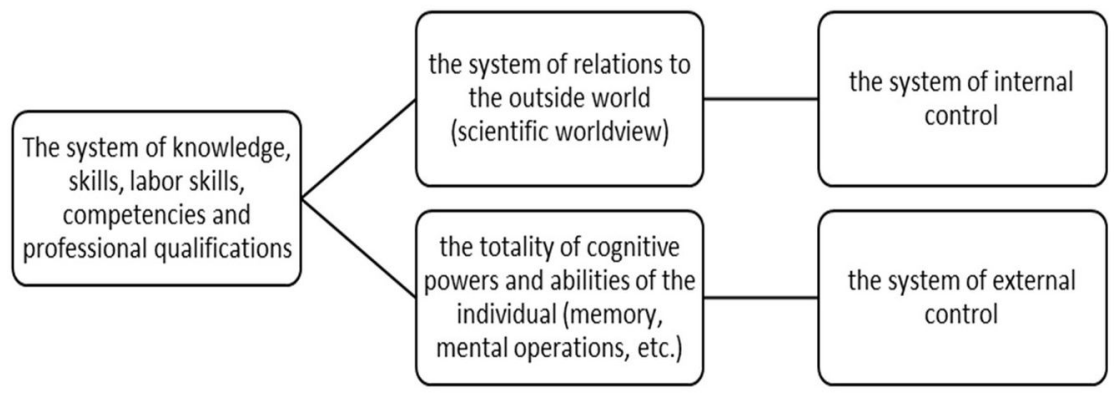

Fig. 1. Diagram of presenting didactics as a theory of education and training

If we shift the scheme of presenting didactics as the theory of education and training to the system of requirements for modern secondary vocational education given in Figure 1, then there arises a necessity to expand the first system and introduce training requirements from the Professional Standard: labour skills and professional qualifications[10, 11]. Then we will get a modified scheme (Figure 2).

- The system of knowledge, skills, labor skills, competencies and professional qualifications $[12,13]$

- the system of relations to the outside world (scientific worldview)

- the totality of cognitive powers and abilities of the individual (memory, mental operations, etc.) $[14,15]$

- the system of internal control

- the system of external control[16, 17]

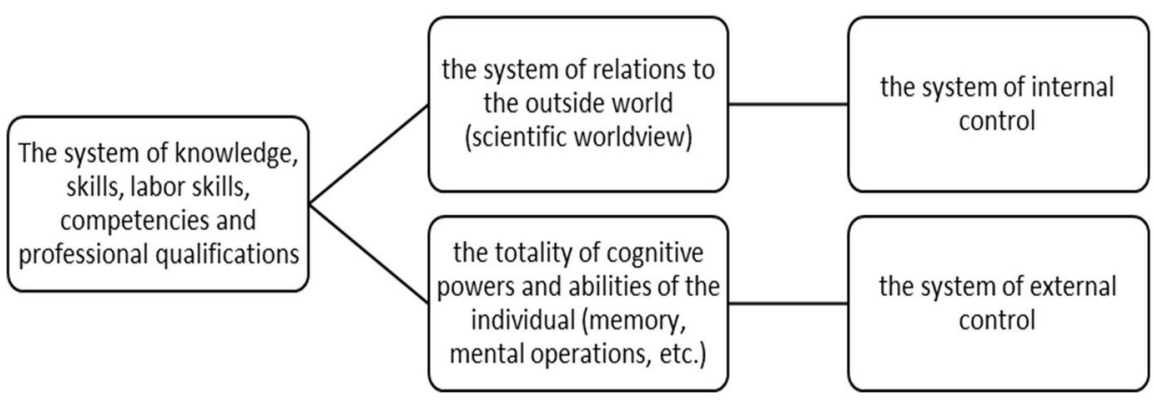


Fig. 2. Diagram of presenting didactics as a theory of education and training, as applied to the system of secondary vocational education

Administering an educational institution, in our case technical colleges, is one of the types of social management in education and is considered by us as the activity of all subjects aimed at ensuring the formation, stabilization, optimal functioning and development of colleges[10, 11].

Under the administration system, many researchers understand the set of interrelated elements, the interaction of which ensures the implementation of management functions and their corresponding effects on the controlled object $[12,13]$. This means that in order to build an administration system, it is necessary to define a set of elements (subsystems) and establish the nature of the connections between them, which allow implementing management functions in achieving the set general goal[14, 15].

Back in 1989, V.P. Bespalko singled out the concept of "didactic system" as part of a general pedagogical system in order to gain a deeper understanding of the processes taking place in it.

\section{Conclusion}

As the general system-forming objective of the system of technical college didactic administration, we have put forward the following goal: to ensure the optimal functioning and development of the managed system, as well as its transfer from the existing to a new, qualitatively higher state.

And as it is described above, in our view, the five interconnected structural parts and, accordingly, three subsystems should be included in our didactic administration system for technical colleges:

The first subsystem is educational. It is focused on organizing and managing students' educational and cognitive activity in colleges and is aimed at forming students' knowledge, skills, work skills, competencies and professional qualifications.

The second subsystem is cognitive. It is ideological in nature, focused on developing students' cognitive abilities and logical thinking.

The third subsystem is the control one. This subsystem consists of two interconnected hierarchically parts - internal and external auditing.

Thus, the system of didactic administration of technical colleges is a set of interrelated didactic components (subsystems) aimed at optimal vocational training of college graduates, involving the acquisition of personally significant qualities demanded by modern high-tech society, namely work skills, general and professional competencies and professional qualifications of students.

\section{References}

1. B. Schults. Scientific visualization: transforming numbers into computer pictures. Computer pictures, 1, 11 (1988)

2. J. D. Russell, Modular instruction. Guidelines for the design, selection, use and evaluation of modular materials. Minneapolis (MN: Burgess Publishing, 1974)

3. M. D. Merrill, The necessary psychological conditions for determining intrastructural results (Educational Design: Reading. Inglewood Cliffs, New Jersey: Prentice Hall 1971)

4. J. P. Guilford, The nature of human intelligence (N. Y.: David McKey Co, 1967)

5. K. Huereca, M. Tchoshanov, M. de la Piedra, Education and self-development 4:38, $217(2013)$ 
6. B. R McDermott, \& M. Tchoshanov, Proceedings of the 41st annual meeting of the Research Council on Mathematics Learning, 34 (2014)

7. R.L. Arroyo, \& M.A. Tchoshanov, Proceedings of the 41th Annual Meeting of the Research Council on Mathematics Learning, 72 (2014)

8. M. Cruz, \& M. Tchoshanov, Proceedings of the 41th Annual Meeting of the Research Council on Mathematics Learning, 138 (2014)

9. L. Bertalanffy, General system theory: Foundations, development, applications. (N-Y: Braziler 1969)

10. S. Bickford, Computer Pictures, 2, 45 (1988)

11. B. Goldschmidt, M. Goldschmidt, Higher Education, 2, 15 (1972)

12. J. P. Guilford, The nature of human intelligence (N.Y.: David McKey Co 1967)

13. M. Lange, Geometry in modules. Teacher's manual (London: Addison Wesley P.C. (1986)

14. M.D. Merrill, Instructional Design: Readings. (Inglewood Cliffs, NJ: Prentice-Hall 1971).

15. Modularization and the new curricular (London : FESC Report, 1986)

16. J.D. Russell. Modular instruction. A guide to the design, selection, utilization and evaluation of modular materials.( Minneapolis, MN: Burgess Publishing 1974)

17. B. Schults, Computer pictures, 1, 11 (1988)

18. J. Szentagothai, Brain Research, 95:4, 475 (1975)

19. The International Encyclopedia of Educational Technology (Ed. by M. Eraut. Oxford: Pergamon Press, 1989) 